体力科学 (2003) 52 Suppl, 119 126

\title{
加需に伴う筋厚, 羽状角および筋束長の変化
}

\author{
久保啓太郎東香寿美金久博 昭 \\ 久野譜也福永哲夫

\section{CHANGES IN MUSCLE THICKNESS, PENNATION ANGLE AND \\ FASCILE LENGTH WITH AGING}

Keitaro Kubo, Kazumi Azuma, Hiroaki Kanemisa. Shinya Kuno and Tetsuo Fukunaga

\begin{abstract}
The influences of age on muscle architectural characteristics, i. e., muscle thickness, pennation angle, fascicle length, were studied in 121 men and 229 women aged 17 to $85 \mathrm{yrs}$. The subjects were divided into three age groups (younger : 17-39 yrs, middle-aged : 40-59 yrs, elderly : 60-85 yrs) for both genders. Muscle thickness and pennation angle of the vastus lateralis (VL), medial gastrocnemius (MG), and long head of triceps brachii (TB) muscles were measured using B-mode ultrasonography, and fascicle length was estimated. In all age groups, men had significantly greater relative muscle thickness (to limb length) in VL and TB than women, but not in MG. Relative muscle thick. ness of VL was significantly lower in elderly than in younger and middle-aged subjects. However, the corresponding differences in MG and TB were insignificant. The pennation angle of VL was significantly lower in elderly than in younger and middle-aged subjects, although there were no significant differences in pennation angles of $M G$ and $\mathrm{TB}$ among the three groups. These results suggest that the decrease in thickness of vastus lateralis muscle with aging is significant, but not significant for medial gastrocnemius and triceps brachii muscles.
\end{abstract}

(Jpn. J. Phys. Fitness Sports Med. 2003, 52 Suppl : 119 126)

key word: pennation, fascicle, muscle thickness, ultrasonograph

\section{I．緒 \\ 言}

加齢に伴う筋の形態や機能の变化については多 くの報告がある，その中で，筋の形態的な変化に ついては, 生理的な萎縮による筋の横断面積の減 少, 速筋線維の選択的な横断面積の減少, 及び筋 線維数の減少が報告されている Young et al. ${ }^{4,5)}$ は, 筋横断面積あたりの筋力が男 性では高齢者群が若年者群よりも低いものの, 女 性にはそのような年齢差がみられないことを示し ている. 最近, Lynch et al. ${ }^{6)}$ は, 単位筋量あたり の筋力は，性及び年齢などの影響を受けることを 示唆している。しかし，加齢に伴う筋横断面積あ たりの筋力の低下及びその性差については, 神経 系, 筋線維夕イプ, 筋形状の影響などが考えられ るが7,8), その詳細なメカニズムについては不明
である。

一方，ヒ卜体肢筋の大部分は羽状筋であり，こ れらの筋においては筋線維(筋束)が筋の長軸方向 (力発揮方向)に対してある角度(羽状角)をもって 腱組織に付着している. Kawakami et al. ${ }^{9.10)}$ は, 超音波Bモード法での測定結果から, 肥大した筋 は羽状角が大きく，また筋力トレーニングによる 筋の肥大は羽状角の増加と筋横断面積あたりの筋 力の低下をもたらすことを報告している.さらに， 筋束長は筋の短縮速度を決定する重要な因子であ ると考えられるが ${ }^{11.12)}$ ，筋肥大に伴い筋束長が 増加することが横断的な研究から明らかにされて いる ${ }^{13)}$. しかしながら，逆の適応として，加齢 による筋萎縮に伴い羽状角や筋束長に減少が生じ るのかついては明らかにされていない.さらに， 男性が女性に比して筋厚や筋横断面積において高
東京大学大学院生命環境科学系

于153-8902 東京都目黑区駒場3-8-1
Department of Life Science (Sports Sciences), University of Tokyo, Komaba 3-8-1. Meguro-ku. Tokyo 153-8902, Japan 
い值を示すことは周知の事実であるが，羽状角や 筋束長の性差に関する報告はごくわずかしかみら れない14,15).

そこで本研究では, 若年龄群, 中年齢群及び高 年齢群の男女における筋厚, 羽状角及び筇束長を 比較することにより，これら筋形状に及ほす年齿 の影響について性差との関連から検討することを 目的とした。

\section{II. 方法}

\section{A. 被検者}

被検者は，日常定期的な運動を行っていない健 康な男女350名であった。本研究では性及び年齢 を基準にして，被検者を男女別々に若年齢群 (17 ～39歳), 中年齢群 (40 -59歳) 及び高年齢群 $(60$ 一 85歳)の 6 群に分類した．各群の身体的特徴は表 1 に示した.各被検者にはあらかじめ研究の目的， 方法，実験に伴う危険性を説明し，書面によって 実験前に実験参加についての同意を得た。なお， 本研究は東京大学大学院生命環境科学系倫理委員 会の承認を得た。

\section{B．筋厚及び羽状角の測定}

Bモード超音波診断装置(アロカ社製，SSD500）を用いて, 先行研究 ${ }^{9,14)}$ と同様な方法によ $\eta$ ，外側広筋 $(\mathrm{VL})$, 腓腹筋内側頭 $(\mathrm{MG})$, 上腕三 頭筋長頭 (TB)の筋厚と羽状角を測定した。測定 部位はそれぞれ大腿長 (大転子から膝窩解)の $50 \%$ ，下腿長(膝煘から脛骨外果)の近位 $30 \%$ ，上 腕長 (肩峰から上腕骨外側上顆)の近位 $60 \%$ であ
り，その部位で最も筋厚が厚くなる部位（筋腹付 近）を測定した。測定に先立ち，皮膚面にペンで マーキングを施した，皮膚に接触する超音波探触 子 $(7.5 \mathrm{MHz})$ 面には超音波用ゼリーを叙布し, 超 音波の伝導性を高めるとともに，皮席を圧迫する ことによる筋の変形が生じないように配慮した。 測定に際し，被検者は立位姿勢で，リラックスし た状態を保ち、肢及び下肢に力を入れないように した。得られた組織横断像において, 皮下脂肪と 各筋の境界と各筋が接する筋 (中間広筋, ヒラメ 筋，上腕三頭筋内側頭）までの距離を筋厚として 計測した，羽状角は，縦断像を用い，それぞれの 筋の深部腱膜と筋束とのなす角として分析した。 筋厚及び羽状角の測定值の再現性については別途 確認した ${ }^{16)}$.

\section{C. 筋束長の推定}

先行研究 ${ }^{11,14)}$ に基づき, 各筋について筋厚と 羽状角から以下の式を用いて筋束長を推定した。 筋束長 $=$ 筋厚 $\cdot \sin (\text { 羽状角 })^{-1}$

\section{D. 統 計}

各測定項目の值はすべて平均土標準偏差で示し た. 各測定項目間の関係は相関分析により検討し， ピアソンの相関係数を求めた. 各群間の比較には, 一元配置の分散分析を行い，要因に有意な効果が 認められた場合には，Scheffe’s post hoc test を用 いて各群間の有意性の検定を行った。いずれも危 険率は $5 \%$ 未満 $(\mathrm{p}<0.05)$ を有意水準とした。

Table 1. Physical characteristics of subjects. Mean(SD)

\begin{tabular}{|c|c|c|c|c|c|c|}
\hline & Younger $(17-39 y$ & & Middle (40-59 yr) & & Older (60-85 yr) & \\
\hline & $\operatorname{Men}(N=71)$ & Women $(N=47)$ & $\operatorname{Men}(N=35)$ & Women $(\mathrm{N}=38)$ & $\operatorname{Men}(N=54)$ & Women $(N=144)$ \\
\hline Age $(y r)$ & $28.9(5.9)$ & $30.0(5.8)$ & $49.1(6.6) \#$ & $50.2(5.0) \#$ & $69.5(4.2) \# \$$ & $68.0(5.3) \# \$$ \\
\hline Height $(\mathrm{cm})$ & $172(5.6)$ & $160(5.7)^{*}$ & $168(5.1)$ & $155(4.9)$ *\# & $161(5.0) \# \$$ & $150(5.6) * \# \$$ \\
\hline Body mass (kg) & $63.7(9.3)$ & $52.2(5.7)^{*}$ & $64.8(7.8)$ & $53.2(7.1)^{*}$ & $60.4(6.1) \# \$$ & $54.0(7.5)^{*}$ \\
\hline Upper arm length $(\mathrm{cm})$ & $31.6(1.6)$ & $29.0(1.5)^{*}$ & $30.9(1.1)$ & $28.9(1.3) *$ & $30.4(1.4) \#$ & $28.8(1.3)^{*}$ \\
\hline Thigh length $(\mathrm{cm})$ & $39.9(2.0)$ & $37.0(2.1)^{*}$ & $38.5(2.2) \#$ & $35.0(1.6) * \#$ & $36.4(1.9) \# \$$ & $33.9(2.0) * \# \$$ \\
\hline Lower leg length $(\mathrm{cm})$ & $39.3(1.8)$ & $35.9(1.6)^{*}$ & $37.4(1.8) \#$ & $34.3(1.7) * \#$ & $35.4(1.7) \# \$$ & $33.1(1.6) * \# \$$ \\
\hline
\end{tabular}




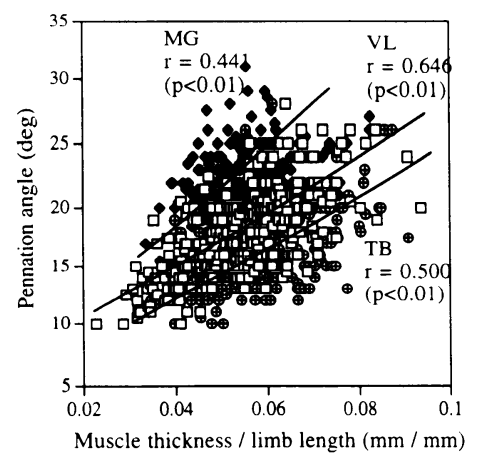

Figure 1. Relationships between relative muscle thickness (to limb length) and pennation angle. $\square$; vastus latelaris (VL), ; medial gastrocne mius (MG). () ; triceps brachii (TB)
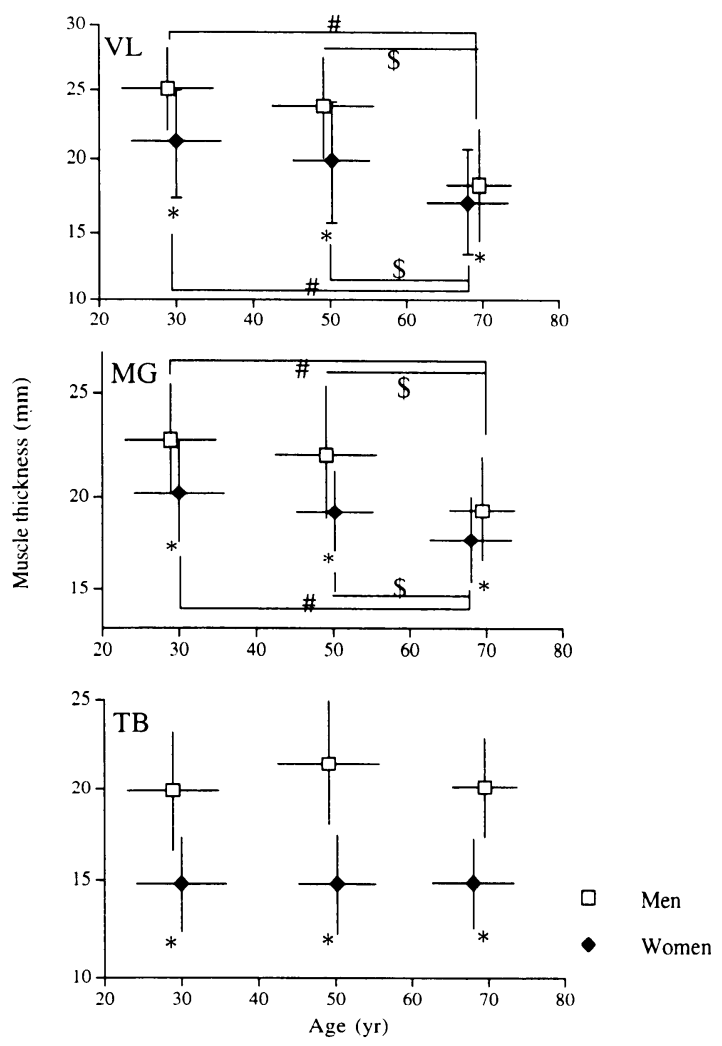

Figure 2. Relationships between age and muscle thickness in vastus iateralis (VL), medial gastrocnemius (MG) and triceps brachii (TB) muscles.

* significant different from men

\# significant different from younger

$\$$ significant different from middle
III. 結

果

筋厚と羽状角との間には有意な正の相関関係が 認められ (VL; $r=0.757, M G ; r=0.513, T B ; r$ $=0.589)$ ，これは筋厚を体肢長当たりに正規化し ても同様であった(図1).

図 2 は, 各群における筋厚を示したものである。 すべての年齢群で男性が女性よりも有意に高い值 を示した. VL 及び MGについては, 男女ともに 高年齢群が他の 2 群よりも有意に低い值を示し た。TBについては，男女ともに加龄による低下 はみられなかった。

図 3 は，各群における体肢長あたりの筋厚を示 したものである。VLについては，若年齢群及び
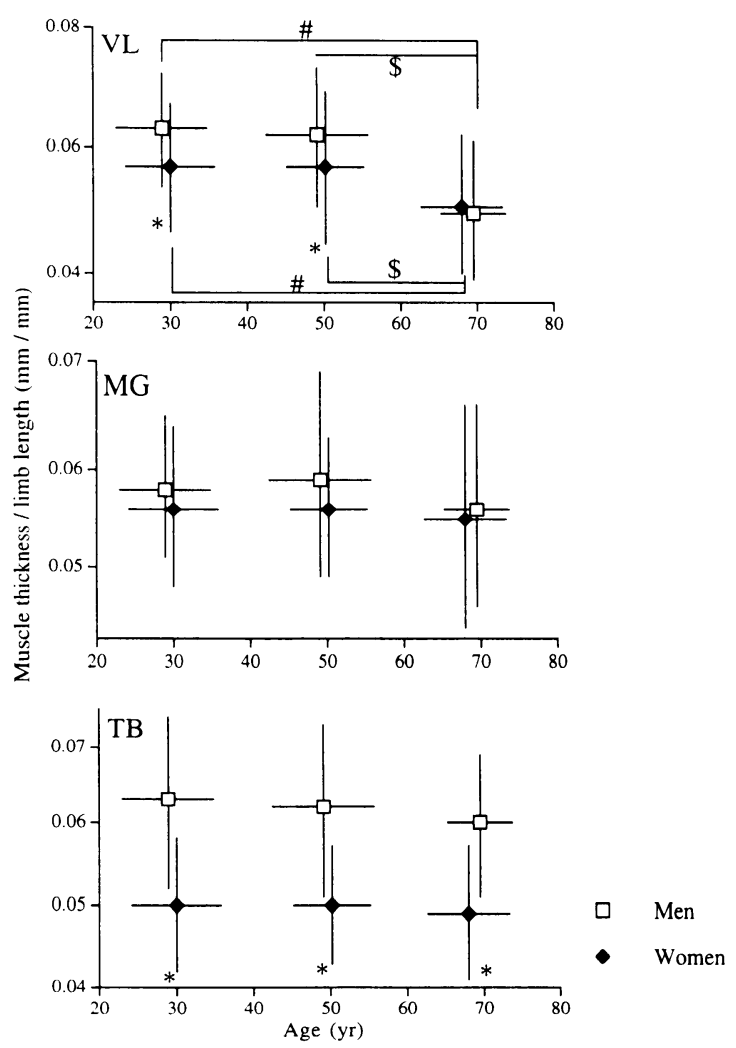

Figure 3. Relationships between age and relative muscle thickness (to limb length) in vastus iater. alis (VL), medial gastrocnemius (MG) and triceps brachii (TB) muscles.

* significant different from men

\# significant different from younger

\$ significant different from middle 

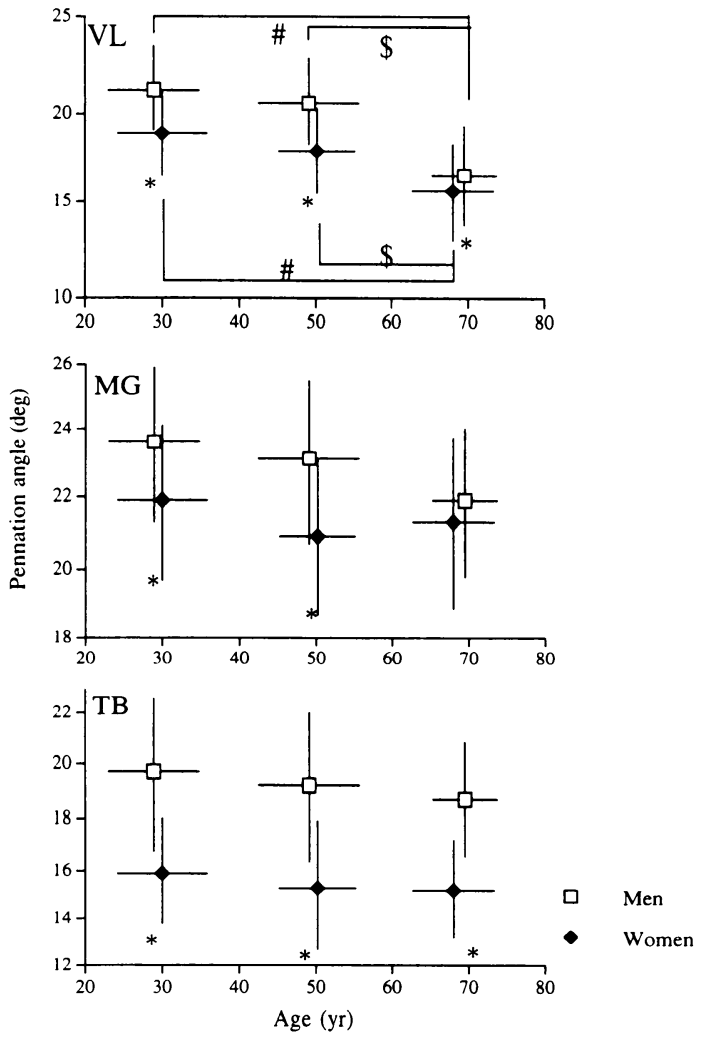

Figure 4. Relationships between age and pennation angle in vastus iateralis (VL), medial gastrocne. mius (MG) and triceps brachii (TB) muscles.

* significant different from men \# significant different from younger $\$$ significant different from middle

中年齢群で男性が女性よりも高い值を示した。さ らに, 男女ともに高年齢群が他の 2 群よりも有意 に低い值を示した，MG については，性及び年齢 による有意な差は認められなかった。TBについ ては，加齢に伴う筋厚の低下は認められなかった ものの，すべての年齢群で男性が女性よりも有意 に高い值を示した。

図 4 は, 各群における羽状角を示したものであ る、VLについては，すべての年齢群で男性が女 性よりも有意に高い值を示した。さらに，男女と もに高年齢群が他の 2 群よりも有意に低い值を示 した.MGについては, 若年齢群及び中年龄群に おいて,男性が女性よりも有意に高い值を示した。 しかし，加齢に伴う低下はみられなかった。TB

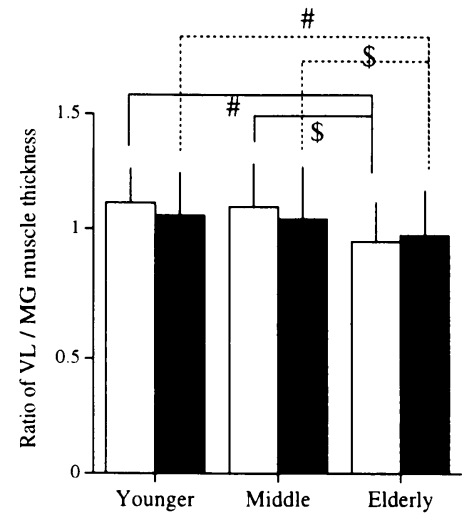

Figure 5. Ratio of muscle thickness of vastus iater. alis $(\mathrm{VL})$ to that of medial gastrocnemius $(\mathrm{MG})$ in men (open) and women (closed).

\# significant different from younger

$\$$ significant different from middle

については，加齢による低下は認められなかった ものの，すべての年齢群で男性が女性よりも有意 に高い值を示した。

図 5 は, MG 筋厚に対する VL 筋厚の比を各群 について示したものである.すべての年齢群で性 差は認められなかった。しかし，男女ともに高年 齢群が他の 2 群よりも有意に低い值を示した。

表 2 は，各群における筋束長及び体肢長あたり の筋束長を示したものである.筋束長については, 若年齢群では男性が女性よりも有意に大きな值を 示した。中年齢群では TBのみ，高年齢群では $\mathrm{MG}$ と TB でのみ男性が女性よりも有意に大きな 值を示した。体肢長あたりの筋束長は，VLにお いて女性が男性よりも長い傾向が認められ，若年 齢群および高年齢群で有意であった(若年齢群； $\mathrm{p}$ $=0.048$, 中年齢群 $; p=0.109$, 高年齢群 $; p=$ 0.028).MG についても同様の傾向が認められた が，統計的に有意な差にまでは至らなかった(若 年齢群 $; p=0.108$, 中年齢群 $; p=0.121$, 高年齢 群; $\mathrm{p}=0.098)$. TB については, すべての年齢 群で体肢長あたりの筋束長に性差は認められなか った。また，3つの筋で体肢長あたりの筋束長に は，年齢による差も認められなかった。

\section{N. 考} 察

本研究では，筋厚，羽状角および筋束長におけ 
Table 2. Fascicle length of six groups. Mean(SD)

\begin{tabular}{|c|c|c|c|c|c|c|c|}
\hline \multirow[b]{3}{*}{ Fascicle length (mm) } & \multicolumn{3}{|c|}{ Younger (17.39 yr) } & \multirow{2}{*}{$\begin{array}{l}\text { Middle }(40-59 \mathrm{yr}) \\
\qquad \operatorname{Men}(\mathrm{N}=35)\end{array}$} & \multicolumn{3}{|c|}{ Older $(60-85 \mathrm{yr})$} \\
\hline & & $\operatorname{Men}(N=71)$ & Women $(N=47)$ & & Women $(\mathrm{N}=38)$ & $\operatorname{Men}(N=54)$ & Women $(N=144)$ \\
\hline & VL & $69.3(7.7)$ & $66.9(10.9) *$ & $67.3(10.1)$ & $68.5(11.9)$ & $64.7(10.5) \# \$$ & $63.6(10.0)$ \\
\hline \multirow{5}{*}{ Fascicle length / limb length $(\mathrm{mm} / \mathrm{mm})$} & MG & $57.5(8.6)$ & $54.3(6.8)^{*}$ & $56.8(9.1)$ & $54.6(8.2)$ & $52.0(7.1) \# \$$ & $48.9(6.0) * \# \$$ \\
\hline & TB & $59.4(9.2)$ & $52.4(6.6)^{*}$ & $59.1(9.0)$ & $52.6(8.2)^{*}$ & $57.5(8.8)$ & $52.1(9.5)^{*}$ \\
\hline & VL & $0.174(0.021)$ & $0.183(0.030) *$ & $0.176(0.031)$ & $0.186(0.034)$ & $0.179(0.033)$ & $0.188(0.033)^{*}$ \\
\hline & MG & $0.147(0.022)$ & $0.151(0.019)$ & $0.153(0.027)$ & $0.160(0.027)$ & $0.147(0.020)$ & $0.153(0.020)$ \\
\hline & $\mathrm{TB}$ & $0.188(0.030)$ & $0.184(0.026)$ & $0.191(0.031)$ & $0.185(0.030)$ & $0.190(0.029)$ & $0.182(0.034)$ \\
\hline
\end{tabular}

* significant different from men

\# significant different from younger

$\$$ significant different from middle

る年齢の影響を性差との関連で検討した。その結 果, 筋厚及び羽状角における加齢に伴う低下は外 側広筋において顕著であること，外側広筋と腓腹 筋内側頭の体肢長あたりの筋束長は，いずれの年 齢群においても女性が男性よりも長い傾向を示す ことが明らかとなった。

筋横断面積や筋厚が加齢に伴い減少することは よく知られた事実である ${ }^{1-3)}$. 本研究でも同様 に，VL と MG の筋厚には加齢に伴う低下が認め られ，これまでの先行研究の結果を支持した(図 2 )。しかし，体肢長あたりの筋厚では，VL が 加齢に伴い低下する傾向を示すものの, MG のそ れには年齢による差がみられなかった。先行研究 では，多くの場合に筋横断面積や筋厚については 「絶対值」が用いられている1 -3) 。しかし，高年 齢群の筋横断面積や筋厚が若年齢群よりも低い値 を示す原因として，身長，体重及び体肢長などの 影響が考えられる，実際に，本研究の 3 つの年齢 群においても，大腿長と下腿長には有意な差が認 められた(表 1$)$. 同様に，多くの先行研究におい ても，身長や体肢長の身体的特徵で高年齢群が 若年齢群よりも有意に低いことが示されてい $る^{1-3)}$ 。さらに本研究では，筋厚と体肢長との 間に有意な正の相関関係が認められた $(\mathrm{VL} ; \mathrm{r}=$ $0.442, \mathrm{MG} ; \mathrm{r}=0.467, \mathrm{~TB} ; \mathrm{r}=0.337)$. 従って, 筋横断面積や筋厚における加齢に伴う変化を検討 する際，身長や体肢長などの影響を考慮する必要 があると考えられる。

一方，VLの体肢長あたりの筋厚は，高年齢群 が他の 2 群よりも有意に低い值を示したものの, 若年齢群と中年齢群との間には有意な差は認めら
れなかった．福永と金久 ${ }^{17)}$ は加齢による筋横断 面積の変化に関して，20歳代から50歳代までの間 では筋横断面積の明らかな年齢差は存在せず，そ れ以降に減少が顕著になったことを報告してい る. Laesson ${ }^{18)}$ は, 11〜 70歳の男性114名を対象 に大腿四頭筋の最大筋力を測定し，筋力は30歳ま では増大し,その後50歳までは変化がなく一定で, 50歳を越えると低下がみられたと報告している。 この他にも, 筋横断面積及び最大筋力の加齢に伴 う低下は60歳代から顕著であるとする報告は多 く，本研究で得られたVLにおける筋厚の加齢低 下の様相は, これまでの先行研究の結果と一致す るものと言える。

また，TB 笳厚には年齢による差がみられなか った。船渡と福永 ${ }^{19)}$ は，身体各部位における加 齢に伴う筋厚の変化について，上肢に比して下肢 における筋厚の低下が著しいことを示している。 筋力についても，下肢に比して上肢における加齢 低下が非常に小さいことが示されている ${ }^{20)}$ 。こ のような部位差の要因については明らかにされて いないが，加齢に伴う日常生活における体重支持 運動(歩行, 走行, 階段昇降など)の減少, すなわ ち下肢の使用頻度の低下が一因ではないかと考え られる ${ }^{21)}$ 。この点に関しては, 今後の検討課題 としたい.

さらに, MG 筋厚に対する VL 筋厚の比が, 高 年齢群が他の 2 群よりも有意に低い值を示した (図 5 )。この結果は, 下腿三頭筋における加齡低 下は大腿四頭筋に比して小さいことを示してい る。すなわち，上述のように上肢に比して下肢の 筋群における加齢低下が著しく，さらに下肢筋群 
の中でも膝伸筋群において顕著であると言える. この原因としては，以下の 2 つことが考えられ る. 1 つ目の理由として，日常生活における活動 レベルが大腿と下腿で異なることが挙げられる。

特に，移動手段としての歩行中において，大腿四 頍筋における相対的な活動レベルが下腿三頭筋よ りも低い可能性が考えられる ${ }^{22,23)}$. 実際に, Ericson et al. ${ }^{22)}$ は，歩行中の筋電図積分值を等尺 性最大筋力 $(M V C)$ 発揮時の值で正規化して, 下 肢筋群の相対的な筋活動レベルを比較したとこ ろ，下腿三頭筋の活動レベル $(40 \% \mathrm{MVC})$ が大腿 四頭筋 $(5 \sim 15 \% \mathrm{MVC})$ よりも高いことを報告し ている. 2 つ目の理由としては，大腿四頭筋と下 腿三頭筋におけるトレーナビリテイの相違が考え られる. 幾つかの先行研究により, 筋力トレーニ ングによる筋力及び筋量の増加の程度が大腿四頭 筋に比して下腿三頭筋は小さいことが示唆されて いる ${ }^{24,25)}$. Weiss et all $^{25)}$ は, 8 週間の高強度卜 レーニングにより，下腿三頭筋の筋力が約 $13 \%$ 増 加したものの筋量の増加はみられなかったことを 示している. 同様に我々は，12週間の筋力トレー ニングにより, 最大筋力及び筋体積の増加率が, 大腿四頭筋では $33 \%$ と $7.5 \%$ であったのに対し， 下腿三頭筋では $18 \%$ と $3 \%$ であったことを報告し ている24.26).このようなトレーニングに対する 両筋群の適応の差が，仮に加齢に伴う萎縮という 過程についてもあてはまるとすれば，VL と MG の筋厚における加齢変化の違いを説明する要因の 一つとして，両筋群間のトレーナビリテイの違い が含まれることになろう。

羽状筋においては, 筋束は筋の長軸方向 (力の 発揮方向)に対してある角度(羽状角)をもって腱 組織に付着している．筋束が発揮した力のうち， 筋の長軸方向に対する成分が関節の回転モーメン トの大きさを決定する。それゆえ，この羽状角は 羽状筋の力発揮特性に影響を及ほす因子として重 要な役割を果たすと考えられる。本研究では, 測 定した 3 筋すべてにおいて筋厚と羽状角の間に有 意な正の相関関係が認められた(図 1). Kawakami et al. ${ }^{9)}$ 及び Abe et al. ${ }^{14)}$ は，それぞれ TB 及び $M G$ を対象にした研究において, 筋厚と羽状角の
間に有意な相関関係がみられたことを報告してい る。これらの結果は, 筋量 (筋厚)の増加は羽状角 の増加を伴うことを示唆するものである. 本研究 では，高年齢群と他の 2 群との間に，VLの羽状 角についてのみ有意な差が認められ， MG と TB には認められなかった。この結果は，上述した体 肢長で正規化した筋厚と同様の結果であった。す なわち，体肢長に対する相対的な筋量(筋厚)が同 程度であれば，羽状角には年齢差が存在しないと 考えられる。一方，羽状角における性差について は，体肢長あたりの筋厚とは異なる結果が得られ た。すなわち，男女における筋の形状は必ずしも 相似形ではなく，構造的に差異を伴うことが示唆 された。この点に関しては，筋束長の性差として 後述する。

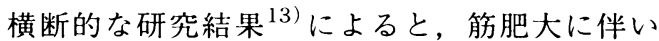
筋束長が増加することが示されている．従って， その逆の現象として，加齡による筋萎縮は筋束長 の低下を伴うことが予想された。しかし，本研究 の結果において，体肢長当たりの筋束長には，年 齢群による差が認められなかった。筋束長／体肢 長比は筋線維長／筋長比を反映していると考えら $れ^{27)}$ ，筋群間及び個人間で差がないと考えられ

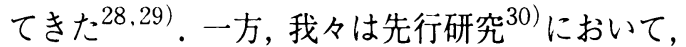
発育期児童における筋束長／体肢長比が成人より も低いことから，発育期には筋の量的な増加のみ ならず，筋の構造も変化していることを示す結果 を得ている．それに対し，本研究の結果は，筋束 長/体肢長比が成人以降の年代においてはほほ一 定であることを示している。しかしながら，筋束 長と体肢長との間には有意な相関関係は認められ ず( $\mathrm{VL} ; \mathrm{r}=0.098, \mathrm{MG} ; \mathrm{r}=0.107, \mathrm{~TB} ; \mathrm{r}=0.020)$, 個人差の大きいことが窅えた。

一方，VLと MGの体肢長あたりの筋束長にお いて，女性が男性よりも長い傾向を示した。同様 に, Chow et al. ${ }^{15)}$ は女性の下腿三頭筋の筋束長 が男性よりも長いことを報告している。 その原因 については明らかではないが，下肢筋群(VL と MG）の体肢長あたりの筋束長が長い女性では, 筋束長に対する腱長の比が低いことが考えられ る. 筋束長は筋の収縮速度を決定する構造的因子 
である ${ }^{27)}$ 。さらに，筋束長に対する腱長の比は サルコメアの短縮量の指標と考えられている31). すなわち，この比が高け机ば高いほど，筋・腱複 合体のコンプライアンスが高く，サルコメアの短 縮量が大きいことになる。つまり，腱長／筋束長 比が低いと予想される女性は弾性エネルギーの再 利用が行われる伸張一短縮サイクル運動におい て,不利な筋の形状を有しているのかもしれない. しかしながら，この点に関しては被検者数を増や し，今後詳細に検討していきたい。

以上の結果，外側広筋については，高年齢群に おける体肢長あたりの筋厚及び羽状角ともに若年 齢群及び中年齢群よりも有意に低く，腓腹筋内側 頭と上腕三頭筋については年齢による差はみられ なかった。このような加齢に伴う筋形状の変化の 部位差は，日常生活における使用頻度およびト レーナビリテイの相違を反映していることが示唆 された。ささらに，いずれの年齢群においても外側 広筋と腓腹筋内側頭の筋束長において女性が男性 よりも長い傾向がみられた。

\section{V. 要約}

本研究では, 筋厚, 羽状角, 筋線維長に及ぼす 年齢の影響を性差との関連で検討することを目的 とした。外側広筋 $(V L)$, 腓腹筋内側頭 $(M G)$ 及び 上腕三頭筋長頭 (TB) の筋束と羽状角を超音波 B モード法により測定し，筋線維長を推定した。 VLについては，体肢長あたりの筋厚及び羽状角 について高年齢群が他の 2 群よりも有意に低い值 を示した。 MG 及び TBについては，体肢長あた りの筋厚及び羽状角ともに年齢による差はみられ なかった。体肢長あたりの筋線維長については, 年齢による差は認められなかったものの, VL と MG に拈いて女性が男性よりも長い傾向がみられ た。このような加齢に伴う筋形状の変化の部位差 は，日常生活における使用頻度やトレーナビリテ イの相違を反映していることが示唆された。

謝 辞

本研究は平成11年度科学技術门：科学技術振興調整 費による研究の一部である。

(受理日 平成15年 3 月20日)

\section{引用 文 献}

1) Hakkinen, K. and Hakkinen, A. Muscle crosssectional area. force production and relaxation char. acteristics in women at different ages. Eur. J. Appl .Physiol. (1991), 62, 410-414.

2) Lexell, J., Taylor, C. C. and Sjiostrom. M. What is the cause of the aging atrophy? Total number, size and propotion of different fiber types studied in whole vastus lateralis muscle from $15-$ to 83 year-old men. J. Neurol. Sci. (1988), 84, 275-294.

3）佐藤広德, 三浦 朗, 佐藤美紀子, 俈藤荡产, 福 場良之。 日本人成人男女 259 名における人腿部筋群 横断面積と筋力の年齢変化について. 体少科学, (1999), 48, 353-364.

4) Young. A., Stokes, M. and Crowe, M. Size and strength of the quadriceps muscles of old and young women. Eur. J. Clin. Invest. (1984), 14, 282-287.

5) Young, A., Stokes M. and Crowe, M. The size and strength of the quadriceps muscles of old and young men. Clin. Physiol. (1985), 5, 145-154.

6) Lynch, N. A., Metter, E. J., Lindle, R. S., Fozard, J. L., Tobin, J. D., Roy, T. A., Fleg, J. L. and Hurley. B. F. Muscle quality. I. Age-associated differences between arm and leg muscle groups. J. Appl. Physiol. (1999), 86, 188-194

7) Brown WF (1988) Methods for estimating numbers of motor units in biceps-brachialis muscles and losses of motor units with aging. Muscle Nerve 11 : 423-432

8) Moritani, T. and deVries, H. A. Potential for gross muscle hypertrophy in older men. J. Gerontol. (1980), 35, 672-682.

9) Kawakami, Y., Abe, T. and Fukunaga, T. Musclefiber pennation angles are greater in hypertrophied than in normal muscles. J. Appl. Physiol. (1993), 74. 2740-2744.

10) Kawakami, Y.. Abe, T., Kuno, S. and Fukunaga, T. Training-induced changes in muscle architecture and specific tension. Eur. J. Appl. Physiol. (1995). 72, $37-43$.

11) Kumagai, K., Abe, T., Brechue, W. F., Ryushi, T.. Takano, S. and Mizuno, M. Sprint performance is related to muscle fascicle length in male $100-\mathrm{m}$ sprinters. J. Appl. Physiol. (2000), 88, 811-816.

12) Sacks, R. D. and Roy, R. R. Architecture of the hind limb muscles of cats: Functional significance. J. Morphol. (1982), 173, 185-195.

13) Kearns, C. F., Abe, T. and Brechue, W. F. Muscle enlargement in sumo wrestlers includes increased muscle fascicle length. Eur. J. Appl. Physiol. (2001), 83, 289-296.

14) Abe, T., Brechue, W. F., Fujita, S. and Brown, J. B Gender differences in FFM accumulation and architectural characteristics of muscle. Med. Sci. Sports Exerc. (1998), 30, 1066-1070.

15) Chow, R. S., Medri, M. K., Martin, D. C., Leekam, R. 
N., Agur, A. M. and McKee, N. H. Sonographic studies of human soleus and gastrocnemius muscle architecture: gender variability. Eur. J. Appl. Phy. siol. (2000), 82, 236-244.

16) Kubo, K., Kanehisa, H., Azuma, K., Ishizu, M., Kuno, S., Okada, M. and Fukunaga, T. Muscle architectural characteristics in women aged 20-79 years. Med. Sci. Sports Exer. (2003). 35, 39-44.

17）福永哲夫, 金久博昭. 日本人の体肢組成. 朝倉書店, 1990.

18) Laesson, L. Morphological and functional charactereistic of the aging skeletal muscle in man. Acta Physiol. Scand. Suppl (1978), 457, 1-36.

19）船渡和男, 福永哲夫. 運動実践の筋力に及ほす効果. J. J. Sports Sci. (1995), 14, 61-65.

20) Bemben, M. G., Massey, B. H., Bemben, D. A., Misner, J. E. and Boileau, R. A. Isometric muscle force production as a function of age in healthy 20-74yr-old men. Med. Sci. Sports Exerc. (1991), 11, 1302-1310.

21) Janssen, I., Heymsfield, S. B., Wang, Z. and Ross, R. Skeletal muscle mass and distribution in 468 men and women aged 18-88 yr. J. Appl. Physiol. (2000). 89, 81-88

22) Ericson, M. O., Nisell, R. and Ekholm, J. Quantified electromyography of lower-limb muscles during level walking. Scand. J. Rehab. Med.(1986), 18, 159163.

23) Winter, D. A. and Yack, H. J. EMG profiles during normal human walking: stride-to-stride and inter- subject variability. Elect. Clin. Neuro. (1987), 67, 402-411.

24) Kubo, K., Kanehisa, H. and Fukunaga, T. Effects of resistance and stretching training programs on the viscoelastic properties of tendon structures in vivo. J. Physiol. (2002), 538, 219-226.

25) Weiss, L. W., Clark, F. C. and Howard, D. G. Effects of heavy-resistance triceps surae muscle training on strength and muscularity of men and women. Physical Therapy (1996), 68, 208-213.

26) Kubo, K., Kanehisa, H., Fukunaga, T. Effects of different duration isometric contractions on tendon stiffness of human quadriceps muscles. J. Physiol. (2001), 536, 649-655.

27) Lieber, R. L. Skeletal muscle structure and function. Wiliams \& Wilkins, (1992), 111-157.

28) Friedrich, J. A and Brand, R. A. Muscle fiber architecture in the human lower limb. J. Biomech. (1990), 23, 91-95.

29) Wickiewcz, T. L., Roy, R. R., Powell, P. L. and Edgerton, V. R. Muscle architecture of human lower limb. Clin. Orthop. Relat. Res. (1983), 179, 317-325.

30) Kubo, K., Kanehisa, H., Kawakami, Y. and Fukunaga, T. Growth changes in the elastic properties of human tendon structures. Int.J.Sports Med (2001), 22, 138-143.

31) Zajac, F. E. Muscle and tendon : properties, models, scaling and application to biomechanics and motor control. CRC Ctrit. Rev. Biomed. Eng. (1989), 17, 359-411. 